\title{
Clinical aspects of trace elements: Zinc in human nutrition - Zinc requirements
}

\author{
Michelle M PluHATOR MSC, ALAN BR THOMSON MD PHD FRCPC FACP FRS FACC, RICHARD N FEDORAK MD FRCPC
}

MM PluHATOR, ABR THOMSON, RN FEDORAK. Clinical aspects of trace elements: Zinc in human nutrition - Zinc requirements. Can J Gastroenterol 1995;9(7):368-372. The body requires certain levels of essential nutrients, such as zinc, to maintain life. Intake less than the required levels can cause impaired function, disease and death. Every essential nutrient has a unique range of tissue concentration and intake necessary for proper physiological and biochemical functioning. Many criteria have been used to set dietary intake levels for nutrients. For trace elements, however, a limited number of investigative approaches are currently employed by researchers due to inadequate information on individual requirements and intake levels. Further, a clear lack of satisfactory biochemical methods to measure zinc nutritional status continues to hinder formulation of dietary guidelines. Thus, many assumptions have to be made, and large safety margins have to be added to assumed daily requirements in order to compensate for this absence of information. Numerous barriers to a full understanding of what constitutes an adequate dietary recommendation for zinc still exist. Zinc is incompletely absorbed, and this absorption can be greatly influenced by the chemical form in which zinc is bound; interactions with other nutrients also affect absorption. Part three of this five-part review presents the current Canadian recommended nutrient intakes for zinc for various sex and age categories and provides a rationale for the suggested values. The important nutrient interactions that affect the bioavailability of zinc, including those with phytates, copper, cadmium, tin and iron, are discussed. (Pour le résumé, voir page 369)

Key Words: Absorption, Enteral, Metabolism, Total parenteral nutrition, Zinc

\footnotetext{
Division of Gastroenterology, Department of Medicine, University of Alberta, Edmonton, Alberta

Correspondence: Dr RN Fedorak, Division of Gastroenterology, Department of Medicine, University of Alberta, 519 Robert Newton Research Building, Edmonton, Alberta T6G 2C2. Telephone 403-492-6941, fax 403-492-3744, e-mail richard.fedorak@ualberta.ca

Received for publication August 16, 1994. Accepted January 23, 1995
}

$T$ HIS REVIEW IS THE THIRD OF A five-part series that examines zinc in terms of its biochemistry and physiology, metabolism, dietary requirements, nutritional assessment and states of excess and deficiency.

Certain levels of essential nutrients, such as zinc, are required to maintain human life. If the body is consistently provided with less than these required amounts, impaired function, disease and death can result. Every essential nutrient has a unique range of tissue concentration and intake necessary for proper physiological and biochemical functioning. Defining these ranges of safe and adequate intake is the goal of human nutrition research.

Although recommendations about dietary zinc intake have been published, zinc requirements and methods for determining zinc's nutritional status continue to be intensively studied. Because of the body's ability to adjust homeostatically to various levels of zinc intake, it has been next to impossible to determine what level of zinc intake is just sufficient and below what level the body cannot compensate. Further, a clear lack of satisfactory biochemical 
Aspects cliniques, biochimiques et physiologiques des éléments trace : zinc et nutrition humaine. Les besoins en zinc

RÉSUMÉ : L'organisme requiert certains taux d'éléments nutritifs essentiels, comme le zinc, pour rester en vie. Un apport insuffisant peut provoquer des dysfonctions, des maladies et même la mort. Chaque élément nutritif essentiel doit être présent dans une concentration tissulaire spécifique et doit être pris en quantité adéquate pour le bon fonctionnement biologique et biochimique de l'organisme. De nombreux critères ont été utilisés pour teuter d'établir quel est l'apport alimentaire idéal de ces éléments nutritifs. Pour les éléments traces toutefois, le nombre d'approches expérimentales actuellement utilisées par les chercheurs est limité à cause du manque de renseignements et de la variabilité des besoins et des apports. De plus, l'absence de méthodologie biochimique satisfaisante pour mesurer le statut nutritionnel en zinc continue de freiner la préparation des directives diététiques. Ainsi, plusieurs suppositions doivent être faites et de bonnes marges de sécurité ont été ajoutées aux exigences quotidiennes pour compenser ces lacunes du savoir. De nombreuses barrières s'opposent toujours à la pleine compréhension de ce qui constitue une recommandation diététique adéquate pour le zinc. Le zinc s'absorbe de façon incomplète et cette absorption peut être grandement influencée par la forme chimique à laquelle le zinc est lié. Les interactions avec d'autres aliments peuvent également en affecter l'absorption. La troisième partie de cette synthèse en cinq volets présente les apports nutritionnels recommandés au Canada pour le zinc, selon l'âge et le sexe et explique la raison d'être de ces recommandations. On y décrit les importantes interactions nutritionnelles qui affectent la biodisponibilité du zinc, y compris les interactions avec les phytates, le cuivre, le cadmium, l'étain et le fer.

TABLE 1

Recommended dietary zinc intakes

\begin{tabular}{lccc}
\hline Age (years) & Sex & $\begin{array}{c}\text { Canadian RNI:* } \\
\text { zinc mg/day }\end{array}$ & $\begin{array}{c}\text { American RDA: } \\
\text { zinc mg/day }\end{array}$ \\
\hline $0-0.3$ & Both & 2.0 & 5.0 \\
$0.4-1$ & Both & 3.0 & 5.0 \\
1 & Both & 4.0 & 10.0 \\
$2-3$ & Both & 4.0 & 10.0 \\
$4-6$ & Both & 5.0 & 10.0 \\
$7-9$ & Both & 7.0 & 10.0 \\
10 & Both & 9.0 & 10.0 \\
11 & Males & 9.0 & 15.0 \\
& Females & 9.0 & 12.0 \\
12 & Males & 9.0 & 15.0 \\
& Females & 9.0 & 12.0 \\
$13+$ & Males & 12.0 & 15.0 \\
& Females & 9.0 & 12.0 \\
Pregnancy & & 15.0 & 15.0 \\
Lactation & & 15.0 & 19.0 \\
First six months & & & 16.0 \\
Second six months & & &
\end{tabular}

*Canadian values from reference $7 ;{ }^{\dagger}$ American values from reference 8. RDA Recommended Dietary Allowance; RNI Recommended Nutrient Intake

methods to distinguish among adequate, marginally deficient and deficient zinc states continues to hinder the formulation of dietary guidelines.

Another barrier to the establishment of adequate dietary recommenda- tions for zinc is its ionic form. Most trace elements, including zinc, occur in the cationic form. Thus, they are incompletely absorbed, and their absorption can be greatly influenced by the chemical form in which they are bound, as well as by interactions with other nutrients. Such factors make it exceptionally difficult to recommend safe and adequate levels of zinc intake for a diverse population which consumes a variable diet.

This review presents the current Canadian recommended nutrient intakes of zinc for various sex and age categories, with a rationale for these suggested values. A discussion of the important nutrient interactions affecting the bioavailability of zinc follows.

\section{HUMAN DIETARY ZINC REQUIREMENTS}

Sources of dietary zinc: Zinc absorption is affected by the amount of zinc in the diet (1), age (2) and the presence of interfering substances (3). In an average adult, 30 to $50 \%$ of the zinc provided daily in the diet is absorbed (4). Major dietary sources of zinc are foods of animal origin such as meat, fish, shellfish, poultry, eggs and dairy products. Whole grain cereals are also good sources of zinc; however, absorption of zinc from these sources is reduced due to the presence of interfering materials such as phytates and fibre. In Canada, an average mixed diet contains approximately $5 \mathrm{mg}$ zinc/1000 kcal (5).

Recommended zinc intake: The apparent lack of readily accessible zinc stores (ie, virtually all the zinc in the body is locked away in bone and protein), coupled with a relatively high endogenous loss of the element, dictates that the body experiences a constant need for dietary zinc to maintain plasma zinc concentrations (6). The recommended nutrient intake for zinc in Canada has been established using a factorial approach, whereby obligatory zinc losses are divided by the fractional absorption to obtain the required amount (7) (Table 1). The recommended zinc intake for males and females over the age of 13 years is 12 and $9 \mathrm{mg} /$ day, respectively (7). This requirement is thought to encompass the needs of the elderly because it is not known whether zinc requirements change in later adulthood. Studies have indicated that the amount of zinc absorbed by the body appears to decline with age. For example, in a study by Turnlund et al (2), a group 
TABLE 2

Elemental antagonists to zinc absorption

\begin{tabular}{l}
\hline Phytic acid (phosphorus) \\
Copper \\
Cadmium \\
Tin \\
Iron \\
\hline
\end{tabular}

of healthy elderly men showed reduced fractional absorption of zinc compared with young control males fed the same diet. The endogenous fecal and urinary losses of the elderly group were less than those of the young men. Thus, the lower zinc absorption of the elderly men was sufficient to replace their endogenous losses. In this study, as well as in others, the older group absorbed about $55 \%$ the amount of zinc absorbed by young adults. As more research is dedicated to the zinc status of the elderly, perhaps changes in the recommended zinc intake will be forthcoming.

The recommended daily zinc intake is increased during pregnancy and lactation. Schraer and Calloway (9) calculated that, in order to allow for a normal pregnancy weight gain, an additional $1.5 \mathrm{mg}$ zinc would have to be retained daily throughout the pregnancy. Given a reported daily zinc intake of $8.9 \pm 3.2 \mathrm{mg}$ by women in the second trimester and applying a safety factor of $2 \mathrm{SD}$, the recommended intake for pregnant women is $15 \mathrm{mg} /$ day. For lactating women, an additional $6 \mathrm{mg} /$ day zinc is required to make up for zinc losses to breast milk (10). This increase raises the zinc requirement for breast-feeding women to $15 \mathrm{mg} /$ day (7).

The recommended dietary zinc intake for infants is based on consumption of breast milk and is set at a recommended intake of $2.0 \mathrm{mg} /$ day for infants from birth to age four months. The requirement for formula-fed infants is likely higher because of the lower bioavailability of zinc in formulas (7). The zinc content of breast milk decreases as postpartum time increases, from $2.6 \pm 0.2 \mu \mathrm{g} / \mathrm{mL}$ at one month to $1.1 \pm 0.1 \mu \mathrm{g} / \mathrm{mL}$ at six months (11). Therefore, infants older than five or six months may not receive adequate zinc from breast milk alone. However, it has been suggested that zinc requirements are highest during the period of early infancy and decrease during later infancy because of a decline in growth velocity (12). If this is so, breast-fed infants likely receive adequate zinc supplies despite the decline in breast milk's zinc content. Due to the lack of adequate data a linear requirement:weight ratio has been assumed for children from six months to 13 years of age (7). Thus, the requirement for children at five to 12 months is $3 \mathrm{mg} /$ day, one to three years is $4 \mathrm{mg} /$ day, four to six years is $5 \mathrm{mg} /$ day, seven to nine years is $7 \mathrm{mg} /$ day and 10 to 12 years is 9 $\mathrm{mg} /$ day. This model does not recognize differences in sex until 13 years of age, when the adult recommended nutrient intake comes into effect.

Zinc bioavailability: In addition to the amount of zinc provided by the diet, its biological availability is an important nutritional consideration. For example, foods from animal sources enhance the absorption and retention of zinc $(7,13)$. Factors that particularly affect the bioavailability of zinc include the phytate found in cereal grains, copper, cadmium, tin and iron $(4,7,13-15)$.

Phytic acid, the major form of phosphorus found in cereal grains and legumes, has long been seen as a potential antagonist of zinc absorption (16) (Table 2). Single-meal studies using radionuclide and stable isotope techniques have confirmed phytic acid's negative effect on zinc absorption in humans. Turnlund et al (2), using levels of phytic acid similar to those found in whole grain and cereal-based diets, observed a significantly reduced absorption of zinc with a liquid formula diet. Similar decreases in zinc absorption were observed when phytic acid was added to white bread (17) and to cow's milk formula (18) at levels close to those observed for wholemeal bread and soy-based formula, respectively.

The framework for understanding the interaction between minerals and trace elements was set by the studies of Hill and Matrone (19). These investigators suggested that minerals with similar chemical properties often engage in biological competition. The zinc ion has parameters identical to those of $\mathrm{Cu}^{+}$and $\mathrm{Cd}^{2+}$, and therefore these elements can be expected to interact with zinc. Such biological interactions between zinc and copper or cadmium are well-documented. The molecular basis of this interaction appears to be a competition for intracellular binding to metallothionein (20).

Using ${ }^{65} \mathrm{Zn}$ and whole-body counting in human subjects, Valberg et al (21) found that $5 \mathrm{mg}$ copper had no effect on the absorption of $0.5 \mathrm{mg}$ zinc in water. The normal human diet almost always contains more zinc than copper. Thus, this interaction has little practical nutritional significance (15). Conversely, large quantities of oral zinc can interfere with copper absorption and, because copper is necessary for iron metabolism, anemia may occur (22). Zinc supplementation may, however, protect against detrimental effects of copper accumulation such as those found in Wilson's disease (23). Zinc acetate is becoming well-established in the treatment of Wilson's disease (24). Zinc acts by inducing the production of intestinal cell metallothionein, which has a high affinity for copper, blocking its absorption and causing its excretion in the feces. Doses of $50 \mathrm{mg}$ zinc bid, taken separate from food, have been shown to control abnormal copper balances, block the uptake of orally administered ${ }^{64} \mathrm{Cu}$, control urine and plasma copper, prevent reaccumulation of hepatic copper and prevent the progression of symptoms of copper toxicosis (24).

A negative interaction has been shown to occur between zinc and cadmium. It has recently been proposed that the use of tobacco products may indirectly affect zinc status. Tobacco products contain cadmium, a trace element toxic to all tissues, which competes with other elements, including zinc, for binding sites on the intestinal mucosa (25). Smokers have also been found to have twice the cadmium tissue concentration of nonsmokers. Thus, indirectly, cadmium from tobacco may decrease zinc metabolism. Additionally, maternal smoking appears to impair the fetal zinc status (25). Kuhnert et al (26) related the birth weight of in- 
fants to zinc:cadmium ratios and postulated that cadmium released from maternal smoking accumulates in the placenta, tying up zinc and reducing fetus growth.

The levels of tin ordinarily found in the human diet are low and unlikely to interfere with zinc absorption (27). Food preserved in unlaquered cans can, however, contain considerable amounts of tin (27). Human metabolic balance studies have shown that tin supplements of $50 \mathrm{mg}$ increase fecal zinc excretion (28) and radiozinc studies have confirmed that tin reduced the zinc absorbed from both a test solution and a meal (21). Solomons and coworkers (29) suggested that tin enhanced zinc excretion because they found that the addition of up to $100 \mathrm{mg}$ tin to an oral dose of $12.5 \mathrm{mg}$ zinc had no significant effect on plasma zinc uptake. While the level of tin used in that study is much higher than that found in the ordinary diet, such amounts are biologically possible if several servings of foods from unlaquered tin cans are ingested within a short time $(20,21)$.

Of greater importance is the competitive interaction between zinc and iron, which both have a mutual affinity

\section{REFERENCES}

1. Wada L, Turnlund JR, King JC. Zinc utilization in young men fed adequate and low zinc intakes. J Nutr 1985;115:1345-54.

2. Turnlund JR, Durkin N, Costa F, Margen S. Stable isotope studies of zinc absorption and retention in elderly men. J Nutr 1986;116:1239-47.

3. Prasad AS. Clinical, biochemical and nutritional spectrum of zinc deficiency in human subjects: an update. Nutr Rev 1983;41:197-208.

4. Guthrie HA. Micronutrient elements. In: Bagby RS, ed. Introductory Nutrition, 7th edn. Toronto: Times Mirror/Mosby College Publishing, 1989:289-335.

5. Kirkpatrick DC, Coffin DE. The trace metal content of representative Canadian diets in 1970 and 1971. Can Inst Food Sci Technol J 1974;7:56-8.

6. Keen CL, Gershwin ME. Zinc deficiency and immune function. Annu Rev Nutr 1990;10:415-31.

7. Health and Welfare Canada. Nutrition Recommendations. Ottawa: Canadian Government Publishing Centre, 1990. for the biological carrier transferrin. A study using bodily retention of ${ }^{65} \mathrm{Zn}$ as an index of absorption found that both inorganic and heme iron inhibited zinc absorption from $6 \mathrm{mg}$ doses of zinc as zinc chloride (21). Inorganic iron, however, had no effect on ${ }^{65} \mathrm{Zn}$ absorption from an extrinsically labelled test meal. Similar results regarding the differential effects of iron on zinc absorption from aqueous solution or meal-based sources have been observed (30). These effects exemplify the complex interactions that take place between promoters and antagonists of absorption; it is important to know that a much higher fraction of zinc is absorbed from an aqueous solution than from food (30). Therefore, interactions with iron may reduce the efficiency of a zinc supplement, while the normal levels of iron enrichment found in foods may not significantly impair absorption of the dietary zinc supply (27). Pharmacological doses of iron are often given to individuals with high zinc requirements such as pregnant women and teenagers (27). In addition, nutritional formulas such as those for infants are often enriched with iron. Thus, the negative effect of iron on zinc absorp-

8. National Research Council. Recommended Dietary Allowances, 10th edn. Washington: National Academy Press, 1989.

9. Schraer KK, Calloway DH. Zinc balance in pregnant teenagers. Nutr Metab 1974;17:205-12.

10. American Academy of Pediatrics. Committee on Nutrition. Nutritional needs of low birth-weight infants. Pediatrics 1977;60:519-30.

11. Moser PB, Reynolds RD. Dietary zinc intake and zinc concentrations of plasma, erythrocytes and breast milk in antepartum and post-partum lactating and nonlactating women: a longitudinal study. Am J Clin Nutr 1983;38:101-8.

12. Krebs NF, Hambidge KM. Zinc requirements and zinc intakes of breast-fed infants. Am J Clin Nutr 1986;43:288-92.

13. Ronaghy HA. The role of zinc in human nutrition. World Rev Nutr Diet 1987;54:237-54.

14. Gordon EF, Gordon RC, Passal DB. Zinc metabolism: basic, clinical, and behavioral aspects. J Pediatr 1981;99:341-9.

15. Solomons NW. Factors affecting the tion could have profound effects on vulnerable groups (27), and some aspects of formula composition of dietary supplementation may have to be rethought taking this fact into account.

\section{CONCLUSIONS}

In view of the current incomplete data on zinc intake and requirements and the absence of a flawless method of analysis, it is very difficult to define human zinc requirements. In addition, human zinc requirements cannot be fully defined without consideration of the dietary source and amount because they both affect whole-body zinc utilization. An understanding of variations in the efficiency with which zinc can be used from different dietary sources remains very limited. Once biochemical methods have been developed that sufficiently reveal changes in zinc status, epidemiological studies will be able to provide much more useful information regarding the relationship between dietary habits and nutritional zinc status. Only then will truly accurate recommendations for the dietary intake of zinc be available for all members of the human population.

bioavailability of zinc. J Am Diet Assoc 1982;80:115-21.

16. O'Dell BL, Savage JE. Effect of phytate on zinc availability. Proc Soc Exp Biol Med 1960;103:304-9.

17. Navert B, Sandstrom B, Cederblad A. Reduction of the phytate content of bran by leavening in bread and its effect on the absorption of zinc in man. Br J Nutr 1985;53:47-53.

18. Lonnerdal B, Cederblad A, Davidson L, Sandstrom B. The effect of individual components of soy formula and cow's milk formula on zinc bioavailability. Am J Clin Nutr 1984;40:1064-70.

19. Hill CH, Matrone G. Chemical parameters in the study of in vivo and in vitro interaction of transition elements. Fed Proc 1970;29:1474-88.

20. Solomons NW. Biological availability of zinc in humans. Am J Clin Nutr 1982;35:1048-75.

21. Valberg LS, Flanagan PR, Chamberlain MJ. Effects of iron, tin and copper on zinc absorption in humans. Am J Clin Nutr 1984;40:536-41.

22. Patterson WP, Winkelmann M, Perry 
MC. Zinc-induced copper deficiency: megamineral sideroblastic anemia. Ann Intern Med 1985;103:385-6.

23. Peereboom JWC. General aspects of trace elements and health. Sci Total Environ 1985;42:1-27.

24. Brewer GJ, Yuzbasiyan-Gurkan V, Lee D. Use of zinc-copper metabolic interactions in the treatment of Wilson's Disease. J Am Coll Nutr 1990;9:487-91.

25. Hennig B, McClain CJ, Diana J. Function of vitamin $\mathrm{E}$ and zinc in maintaining endothelial integrity: implications in atherosclerosis. Ann NY Acad Sci 1993;686:99-109.

26. Kuhnert BR, Kuhnert PM, Debanne S, Williams TG. The relationship between cadmium, zinc and birthweight in pregnant women who smoke. Am J Obstets Gynecol 1987;157:1247-51.

27. Oberleas D, Muhrer ME, O’Dell BL. Dietary metal-complexing agents and zinc availability in the rat. J Nutr 1966;90:56-62.

28. Johnson MA, Baier MJ, Greger JL. Effects of dietary tin on zinc, copper, iron, manganese metabolism of adult males. Am J Clin Nutr 1982;35:1332-8

29. Solomons NW, Marchini JS, Duarte-Favaro RM, Vannuchi H, Dutra de Oliveira JE. Studies on the bioavailability of zinc in humans: intestinal interaction of tin and zinc. Am J Clin Nutr 1993;37:566-71.

30. Sandstrom B, Davidsson L, Cederblad A, Lonnerdal B. Oral iron dietary ligands and zinc absorption. J Nutr 1985;115:411-4. 


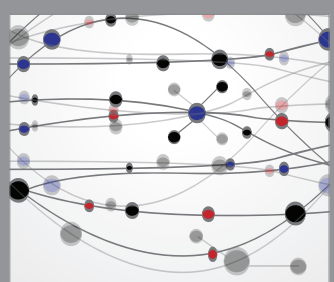

The Scientific World Journal
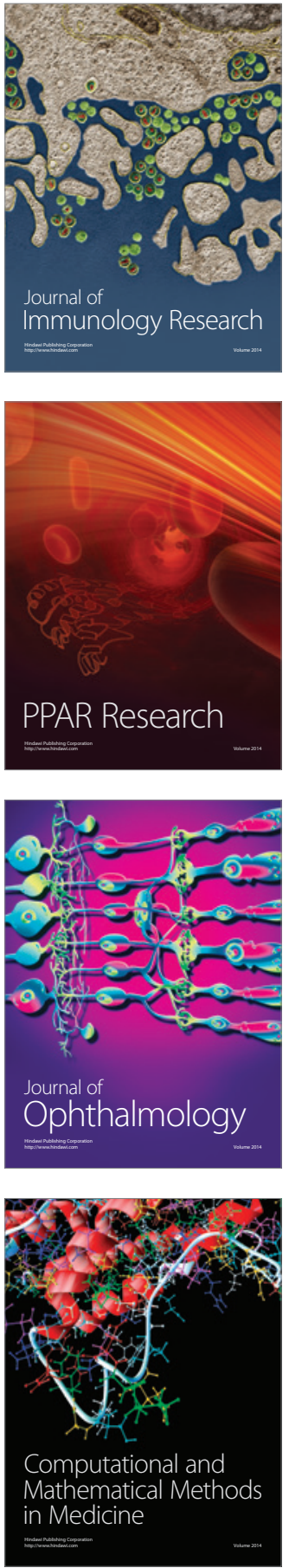

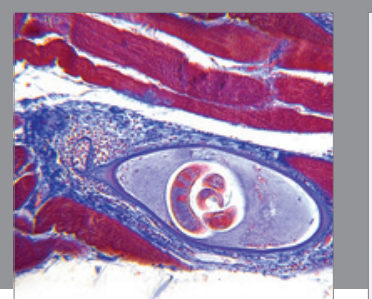

Gastroenterology Research and Practice

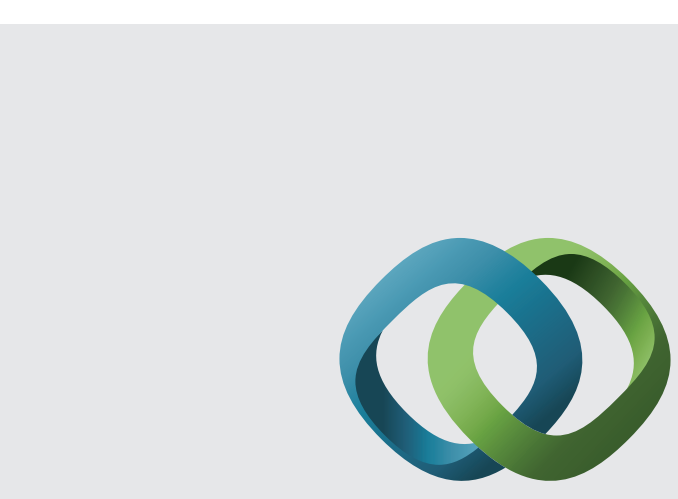

\section{Hindawi}

Submit your manuscripts at

http://www.hindawi.com
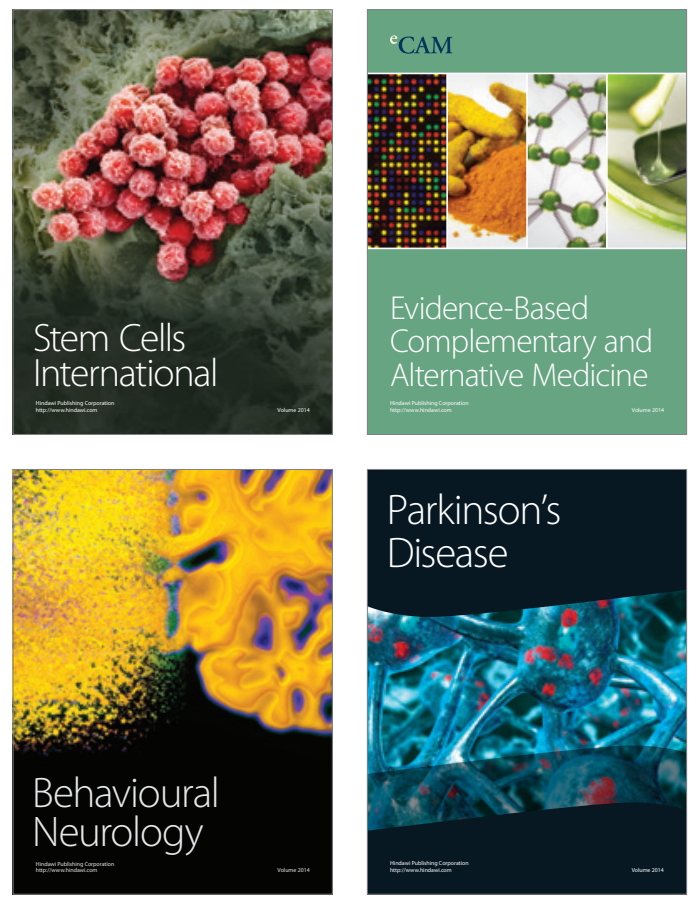
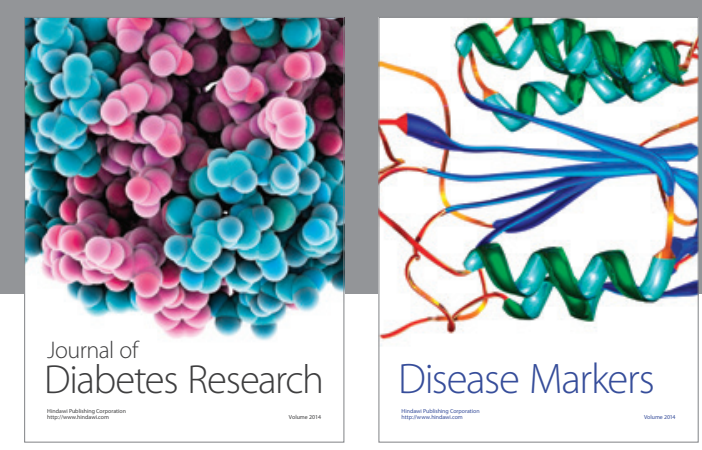

Disease Markers
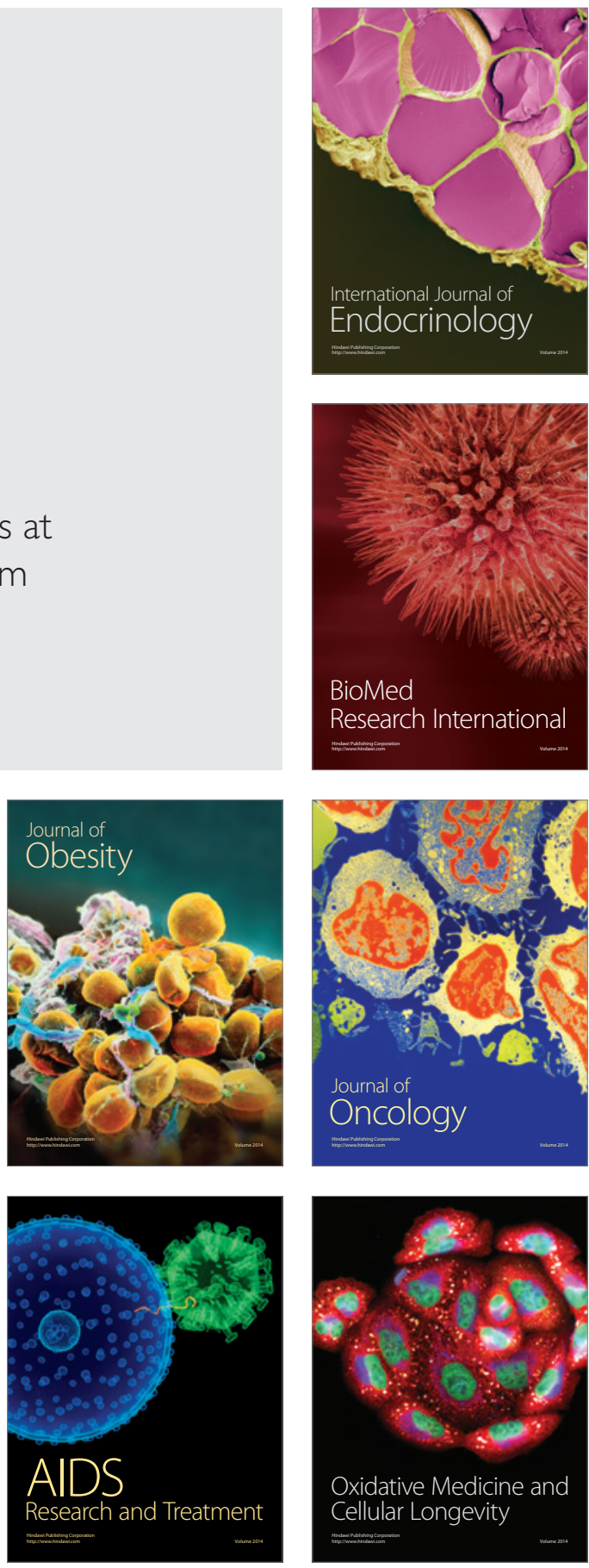